\title{
Do peak torque angles of muscles change following anterior cruciate ligament reconstruction using hamstring or patellar tendon graft?
}

\author{
Hamstring ya da patellar tendon grefti kullanılan ön çapraz bağ rekonstrüksiyonu sonrası \\ kasların zirve tork açıları değişir mi?
}

\author{
Hayri Baran Yosmaoğlu, PT, PhD., ${ }^{1}$ Gül Baltacı, PT, PhD., ${ }^{2}$ Emel Sönmezer, PT, PhD., \\ Hamza Özer, MD., ${ }^{3}$ Deha Doğan, PhD. ${ }^{4}$

\begin{abstract}
'Department of Physical Therapy and Rehabilitation, Faculty of Health Sciences, Baskent University, Ankara, Turkey
${ }^{2}$ Department of Physiotherapy and Rehabilitation, Private Guven Hospital, Ankara, Turkey

${ }^{3}$ Department of Orthopedics and Traumatology, Faculty of Medicine, University of Gazi, Ankara, Turkey

${ }^{4}$ Department of Measurement and Evaluation, Faculty of Educational Sciences, University of Ankara, Ankara, Turkey
\end{abstract}

\begin{abstract}
Objectives: This study aims to compare the effects of anterior cruciate ligament (ACL) reconstruction using autogenous hamstring or patellar tendon graft on the peak torque angle.

Patients and methods: The study included 132 patients (103 males, 29 females; mean age 29 \pm 9 year) who were performed ACL reconstruction with autogenous hamstring or patellar tendon graft. The peak torque angles in the quadriceps and hamstring muscles were recorded using an isokinetic dynamometer.

Results: Angle of peak knee flexion torque occurred significantly earlier within the range of motion on the operated side than nonoperated side at $180 \%$ second in the hamstring tendon group. Angle of peak knee extension torque occurred significantly earlier within the range of motion on the operated side than nonoperated side at $180 \%$ second in the patellar tendon group. There were no statistically significant differences in the flexion and extension peak torque angles between the operated and nonoperated knees at $60 \%$ second in both groups.
\end{abstract}

Conclusion: The angle of peak torque at relatively high angular velocities is affected after ACL reconstruction in patients with hamstring or patellar tendon grafts. The graft donor site directly influences this parameter. This finding may be important for clinicians in terms of preventing re-injury.

Keywords: Athletic performance; hamstring tendon graft; muscle strength dynamometer; patellar tendon graft; torque.
$\ddot{O Z Z}$

Amaç: Bu çalışmada, otojen hamstring veya patellar tendon grefti kullanılan ön çapraz bă̆ (ÖÇB) rekonstrüksiyonun zirve tork açısı üzerindeki etkileri karşılaştırıldı.

Hastalar ve yöntemler: Çalışmaya otojen hamstring veya patellar tendon grefti ile ÖÇB rekonstrüksiyonu uygulanan 132 hasta (103 erkek, 29 kadın; ort. yaş $29 \pm 9$ yıl) dahil edildi. Kuadriseps ve hamstring kaslarındaki zirve tork açıları izokinetik dinamometre kullanılarak kaydedildi.

Bulgular: Hamstring tendon grubunda zirve diz fleksiyonu tork açısı hareket açıklığında ameliyat edilen tarafta ameliyat edilmeyen taraftan $180 \%$ saniyede anlamlı şekilde daha erken oluştu. Patellar tendon grubunda zirve diz fleksiyonu tork açısı hareket açıklığında ameliyat edilen tarafta ameliyat edilmeyen taraftan $180 \%$ saniyede anlaml şekilde daha erken oluştu. Her iki grupta ameliyat edilen ve edilmeyen dizler arasında $60 \%$ saniyede fleksiyon ve ekstansiyon zirve tork açılarında istatistiksel olarak anlamlı farklılıklar yoktu.

Sonuç: Göreceli olarak yüksek açısal hızlarda zirve tork açısı ÖÇB rekonstrüksiyonu sonrasında hamstring veya patellar tendon grefti olan hastalarda etkilenmektedir. Greft donör sahası bu parametreyi doğrudan etkilemektedir. $\mathrm{Bu}$ bulgu yeniden yaralanmanın önlenmesi açısından klinisyenler için önemli olabilir.

Anahtar sözcükler: Atletik performans; hamstring tendon grefti; kas gücü dinamometresi; patellar tendon grefti; tork.

- Received: January 26, 2017 Accepted: July 25, 2017

- Correspondence: Hayri Baran Yosmaoğlu, PT, PhD. Başkent Üniversitesi Sağlık Bilimleri Fakültesi, Fizik Tedavi ve Rehabilitasyon Anabilim Dalı, 06790 Bağlıca, Ankara, Turkey. Tel: +90 312 - 2466673 e-mail: hayribaran@baskent.edu.tr 
Rehabilitation of the hamstring and quadriceps muscles is important before and after anterior cruciate ligament (ACL) reconstruction. ${ }^{[1]}$ Past research has shown a significant postoperative deficit in isokinetic muscle test parameters such as peak muscle torque, total work and power which may lead to osteoarthritis. ${ }^{[2-9]}$ These deficits were found to be associated with the location of the donor site..$^{[10]}$ Previous research has also focused specifically on the quality of torque production as demonstrated by isokinetic torque curve irregularities, curve fluctuations, a rapid downward slope pattern, and a concave pattern when viewed on a graph following ACL reconstruction. Patients with both ruptured and reconstructed ACLs have been shown to demonstrate the above-mentioned irregularities compared with healthy knees. ${ }^{[11-14]}$ The angle of peak torque, however, has not been comprehensively investigated. This parameter is defined as the flexion or extension angle at which peak torque occurs. The clinical importance of this angle lies in the fact that a shift in the angle of peak torque in the hamstring muscle reportedly increases the susceptibility to injury and makes the hamstrings more prone to damage from eccentric loads. ${ }^{[15,16]}$ Further knowledge about the angle of peak torque, therefore, may be important for patients who are ACL-deficient or have undergone reconstruction because both conditions are associated with deficits in neuromuscular control following injury. ${ }^{[17]}$ An understanding of the injury mechanism and risk factors is crucial to prevent recurrence in patients who have undergone ACL reconstruction. Accordingly, in this study, we aimed to compare the effects of ACL reconstruction using autogenous hamstring or patellar tendon graft on the peak torque angle.

\section{PATIENTS AND METHODS}

This prospective cohort study was conducted at Hacettepe University, Faculty of Health Sciences Department of Physiotherapy and Rehabilitation between January 2007 and August 2009 included 132 patients (103 males, 29 females; mean age $29 \pm 9$ ) who were performed ACL reconstruction with autogenous hamstring $(\mathrm{n}=101)$ or patellar $(\mathrm{n}=31)$ tendon graft (Table I). Dependent variable was the angle of peak torque generated by hamstring and quadriceps muscles while independent variables were the hamstring or patellar tendon graft types. All surgical procedures were performed by two orthopedic surgeons with a minimum of 10 years of experience in ACL reconstruction. Patients with multiple injuries or a history of previous knee surgery were excluded. None of the patients were professional athletes. Sixteen patients (10 who underwent patellar tendon harvest, six who underwent hamstring tendon harvest) described themselves as recreationally active; the rest declared a sedentary lifestyle. All patients followed the same postoperative rehabilitation program. The average duration between surgery and isokinetic testing in the hamstring and patellar tendon groups was $12 \pm 5$ months and $14 \pm 6$ months, respectively. Follow-up assessments were also performed on these dates. The study protocol was approved by the Hacettepe University Ethics Committee. A written informed consent was obtained from each patient. The study was conducted in accordance with the principles of the Declaration of Helsinki.

All patients started rehabilitation during the first postoperative week. The 12-week program involved a rehabilitation session three times a week. Early range of motion exercises were encouraged in the first three weeks. Patients were allowed weightbearing as tolerated. Closed kinetic chain exercises were performed to increase knee flexion. Prone hanging leg extension was used to prevent extension limitation. Hip abduction-adduction exercises, the straight leg raise, and isometric quadriceps sets were performed to increase muscle control. Cycling, theraband strength training, mini squats, and coordination exercises on the balance board and soft ground started in postoperative third to fourth weeks. Resistive knee flexion/extension exercises were introduced after six to eight weeks. Jogging was allowed at 14 to 16 weeks.

TABLE I

Patient demographics

\begin{tabular}{|c|c|c|c|c|c|c|c|c|c|c|c|c|c|c|c|}
\hline & \multicolumn{5}{|c|}{ Age (year) } & \multicolumn{5}{|c|}{ Height (cm) } & \multicolumn{5}{|c|}{ Body mass (kg) } \\
\hline & \multicolumn{2}{|c|}{ PT group } & \multicolumn{2}{|c|}{ HT group } & \multirow[b]{2}{*}{$p$} & \multicolumn{2}{|c|}{ PT group } & \multicolumn{2}{|c|}{ HT group } & \multirow[b]{2}{*}{$p$} & \multicolumn{2}{|c|}{ PT group } & \multicolumn{2}{|c|}{ HT group } & \multirow[b]{2}{*}{$p$} \\
\hline & $\mathrm{n}$ & Mean \pm SD & $\mathrm{n}$ & Mean $\pm S D$ & & $\mathrm{n}$ & Mean $\pm S D$ & $\mathrm{n}$ & Mean \pm SD & & $\mathrm{n}$ & Mean \pm SD & $\mathrm{n}$ & Mean \pm SD & \\
\hline Female & 7 & $29 \pm 14$ & 21 & $26 \pm 9$ & NS & 7 & $167 \pm 8$ & 21 & $167 \pm 5$ & NS & 7 & $58 \pm 4$ & 21 & $61 \pm 6$ & NS \\
\hline Male & 25 & $28 \pm 8$ & 78 & $30 \pm 8$ & NS & 25 & $174 \pm 5$ & 78 & $176 \pm 7$ & NS & 25 & $76 \pm 9$ & 78 & $77 \pm 8$ & NS \\
\hline
\end{tabular}

PT: Patellar tendon graft group; HT: Hamstring tendon graft group; SD: Standard deviation; NS: Not statistically significant on independent-samples t-test ( $<<0.05$ ). 
The angle of peak torque during concentric contractions of the quadriceps and hamstring muscles was recorded using an IsoMed 2000 dynamometer (D\&R GmbH, Hemau, Germany). Warm-up consisted of hamstring/quadriceps stretching exercises and cycling on a stationary bike for five minutes. Patients were seated on the dynamometer with their knees flexed to $90^{\circ}$ and the center of their knee joint lined up with the pivot point of the crank arm. Shoulder, pelvis, and knee stabilization straps were used to prevent substitution and unwanted movements. Five practice repetitions of knee flexion/extension were performed at $60 \%$ second and $180 \%$ second angular velocities, respectively, to familiarize the

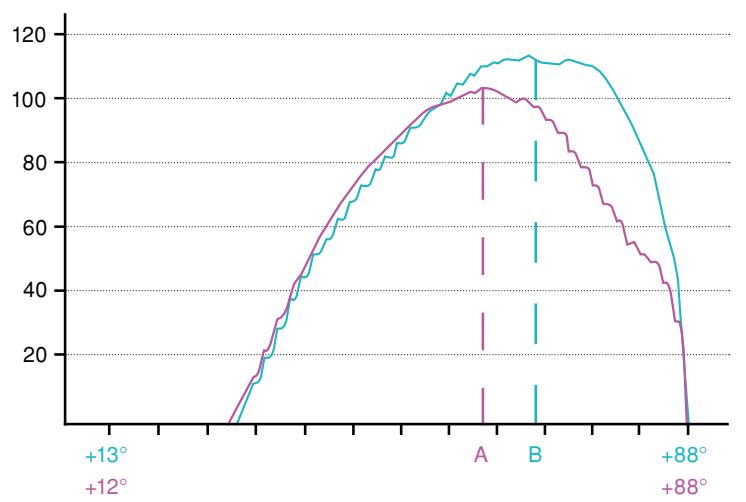

Figure 1. Graphic sample of angle of peak torque generated by quadriceps muscle. $X$ axis represents knee angle in range of motion, and y axis represents torque generated in isokinetic test. A represents angle of peak quadriceps muscle torque generated by operated knee at $180 \%$ second angular velocity. B represents angle of peak quadriceps muscle torque generated by nonoperated knee at $180 \%$ second angular velocity.

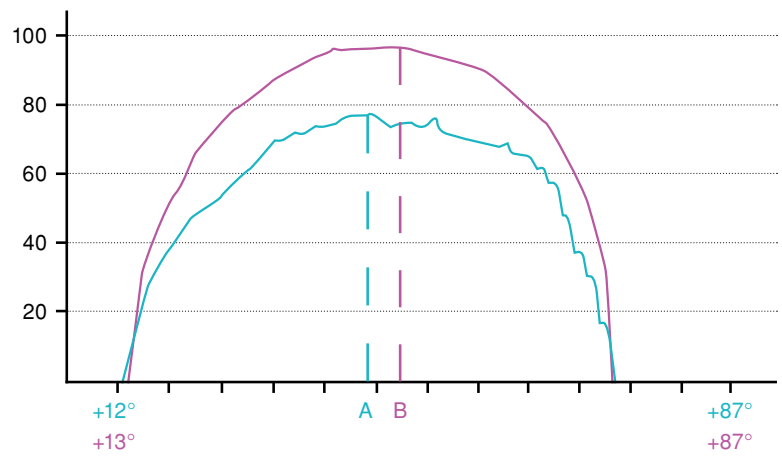

Figure 2. Graphic sample of angle of peak torque generated by hamstring muscle. $X$ axis represents knee angle in range of motion, and y axis represents torque generated in isokinetic test. A represents angle of peak hamstring muscle torque generated by operated knee at $180 \%$ second angular velocity. $B$ represents angle of peak hamstring muscle torque generated by nonoperated knee at $180 \%$ second angular velocity. patients with isokinetic training prior to testing. The patients stated that they experienced no pain or discomfort. The isokinetic testing involved one set of 10 repetitions at $180 \%$ second, then one set of five repetitions at $60 \%$ second. One minute of recovery was given between each set. The procedures were repeated on the nonoperated knee. The angle of peak torque was calculated by the dedicated software of the IsoMed 2000. Graphic samples of the angle of peak torque generated by the quadriceps and hamstring muscles were shown in Figures 1 and 2.

\section{Statistical analysis}

All data were analyzed with the PASW version 17.0 (SPSS, Inc., Chicago, IL, USA). Multivariate analysis of variance was used to compare the dependent variable (angle of peak torque) between the operated and nonoperated sides in both the hamstring tendon and patellar tendon graft groups. A power analysis based on previous studies by Brockett et al. ${ }^{[15]}$ and Proske et al., ${ }^{[16]}$ in which the mean peak torque angle of the previously injured hamstring muscles was $12^{\circ}$ shorter than that of the uninjured side, showed that two groups of 28 patients each would be the minimum required to demonstrate a $95 \%$ difference in the angle of peak torque with a type I error of 0.05 and a type II error of 0.01 . Statistical significance was set at $p<0.05$.

\section{RESULTS}

The angle of peak knee flexion torque occurred later within the range of motion in the patellar tendon than hamstring tendon group at angular velocities of $60 \%$ second and $180 \%$ second ( $\mathrm{p}=0.03$ and $\mathrm{p}=0.04$, respectively) (Table II). The angle of peak knee extension torque occurred earlier within the range of motion in the patellar tendon than hamstring tendon group at $180^{\circ} /$ second $(p=0.02)$. There was no difference in the peak torque angle in knee extension at $60 \%$ second between the two groups $(\mathrm{p}>0.05)$.

The angle of peak knee flexion torque occurred earlier within the range of motion on the operated side than nonoperated side at $180 \%$ second in the hamstring tendon graft group ( $\mathrm{p}=0.04)$ (Table III). The angle of peak knee extension torque also occurred earlier within the range of motion on the operated side than nonoperated side at $180 \%$ second in the patellar tendon group $(\mathrm{p}=0.04)$. There were no differences in the flexion and extension peak torque angles between the operated and nonoperated knees at $60 \%$ second in either group, in the flexion peak torque angle between the operated and nonoperated knees at $180 \%$ second in the patellar tendon group, or in the extension peak torque angle between the operated and nonoperated 
TABLE II

Differences in peak torque angle in operated knees between patellar and hamstring tendon graft groups

\begin{tabular}{|c|c|c|c|c|}
\hline & Hamstring tendon graft group & Patellar tendon graft group & & \\
\hline & Mean $\pm S D$ & Mean $\pm S D$ & $\mathrm{~F}$ & $p$ \\
\hline \multicolumn{5}{|l|}{ Flexion } \\
\hline Peak torque angle at $60 \%$ second & $39.4^{\circ} \pm 10.0^{\circ}$ & $43.8^{\circ} \pm 9.7^{\circ}$ & 0.03 & $0.03^{*}$ \\
\hline Peak torque angle at $180 \%$ second & $32.5^{\circ} \pm 7.4^{\circ}$ & $35.7^{\circ} \pm 8.9^{\circ}$ & 0.67 & $0.04^{*}$ \\
\hline \multicolumn{5}{|l|}{ Extension } \\
\hline Peak torque angle at $60 \%$ second & $61.7^{\circ} \pm 8.5^{\circ}$ & $61.6^{\circ} \pm 9.2^{\circ}$ & 0.49 & NS \\
\hline Peak torque angle at $180 \%$ second & $62.2^{\circ} \pm 7.3^{\circ}$ & $65.7^{\circ} \pm 7.5^{\circ}$ & 0.30 & $0.02^{*}$ \\
\hline
\end{tabular}

SD: Standard deviation; * Statistically significant $(p<0.05)$; NS: Not statistically significant on multivariate analysis of variance.

TABLE III

Comparison of peak torque angle between operated and nonoperated knees in hamstring and patellar tendon graft groups

\begin{tabular}{|c|c|c|c|c|c|c|c|c|}
\hline & \multicolumn{4}{|c|}{ Hamstring tendon graft group } & \multicolumn{4}{|c|}{ Patellar tendon graft group } \\
\hline & Operated & Nonoperated & & & Operated & Nonoperated & & \\
\hline & Mean $\pm S D$ & Mean $\pm S D$ & $\mathrm{~F}$ & $p$ & Mean $\pm S D$ & Mean $\pm S D$ & $\mathrm{~F}$ & $p$ \\
\hline \multicolumn{9}{|l|}{ Flexion } \\
\hline Peak torque angle at $60 \%$ second & $39.4^{\circ} \pm 10.0^{\circ}$ & $41.0^{\circ} \pm 10.9^{\circ}$ & 1.4 & NS & $43.8^{\circ} \pm 9.7^{\circ}$ & $43.3^{\circ} \pm 11.4^{\circ}$ & 0.45 & NS \\
\hline Peak torque angle at $180 \%$ second & $32.5^{\circ} \pm 7.4^{\circ}$ & $35.0^{\circ} \pm 9.8^{\circ}$ & 2.3 & $0.04^{*}$ & $35.7^{\circ} \pm 8.9^{\circ}$ & $34.2^{\circ} \pm 7.8^{\circ}$ & 0.82 & NS \\
\hline \multicolumn{9}{|l|}{ Extension } \\
\hline Peak torque angle at $60 \%$ second & $61.7^{\circ} \pm 8.5^{\circ}$ & $63.5^{\circ} \pm 6.3^{\circ}$ & 5.4 & NS & $61.6^{\circ} \pm 9.2^{\circ}$ & $63.2^{\circ} \pm 6.4^{\circ}$ & 5.90 & NS \\
\hline Peak torque angle at $180 \%$ second & $62.2^{\circ} \pm 7.3^{\circ}$ & $61.3^{\circ} \pm 6.6^{\circ}$ & 1.0 & NS & $65.7^{\circ} \pm 7.5^{\circ}$ & $62.0^{\circ} \pm 6.8^{\circ}$ & 0.94 & $0.04^{*}$ \\
\hline
\end{tabular}

SD: Standard deviation; ${ }^{*}$ Statistically significant $(p<0.05)$; NS: Not significant on multivariate analysis of variance.

knees at $180^{\circ}$ /second in the hamstring tendon group ( $p>0.05$ for all).

\section{DISCUSSION}

The findings of this study show that ACL-reconstructed knees have differences in the angle of peak torque and that the choice of graft (hamstring vs. patellar tendon) influences the peak torque angle. When the graft was harvested from extensor muscles, the angle of peak knee extension torque (at $180 \%$ second) shifted toward flexion, and when the graft was harvested from flexor muscles, the angle of peak flexion torque (at $180 \%$ second) shifted toward extension. That is, peak torque occurred at shorter flexion angles in both the hamstring and patellar tendon groups. This finding may be important for clinicians because previous studies, although limited, suggest that a shift in angle of the peak torque in the hamstring muscle may cause increased susceptibility to injury and make the hamstrings more prone to damage from eccentric exercise. ${ }^{[15,16]}$ It was demonstrated that the torque peaked at significantly shorter lengths in injured muscles even when the peak torque and quadriceps/hamstrings torque ratios were not significantly different between previously injured muscle and uninjured muscle. ${ }^{[15,16]}$ This makes injured muscle more prone to damage from eccentric exercise than uninjured muscle, which may account for higher re-injury rates. Brockett et al. ${ }^{[15]}$ stated that injured hamstring muscle had an optimum angle of $53.5^{\circ}$, which differed by almost $16^{\circ}$ from the optimum of hamstrings on the uninjured side $\left(37.5^{\circ}\right)$, so that torque generated by the previously injured muscle peaked at a much shorter length than on the uninjured side. This finding supports the results of our study; however, in contrast to the study by Proske et al., ${ }^{[16]}$ we found that peak torque occurred at shorter flexion angles (longer lengths) in operated legs. The morphological features of the semitendinosus muscle as part of the hamstring could explain the shift in the peak torque after ACL reconstruction with a semitendinosus graft. The semimembranosus and biceps femoris are unipennate muscles. They have short fiber lengths and pennation angles. However, the fiber length of the semitendinosus and gracilis is three to four 
times longer than that of the semimembranosus and biceps femoris. ${ }^{[18]}$ After semitendinosus harvest, the semimembranosus and biceps femoris are left as the primary knee flexors; however, these muscles are insufficient to produce torque, especially at deeper flexion angles. This could also cause an earlier angle of peak torque in the operated leg.

Neuromuscularimpairmentof themechanoreceptor mechanism of the ACL may explain the differences between operated and nonoperated knees. There is a direct link among the ACL, the muscles around the knee, ${ }^{[19,20]}$ and the cruciate ligament receptors via the reflex modulation of the gamma-muscle-spindle system, which may participate in the regulation and preprogramming of the muscular stiffness around the knee joint. ${ }^{[21]}$ Moreover, it has been demonstrated that muscular contraction or inhibition of the muscle activity in the contracting muscles could beelicited with nonpainful electrical stimuli to the ACL in humans. ${ }^{[20]}$ The mechanoreceptor system is disturbed after injury, and reconstruction may not restore this modulation mechanism. Bryant et al. ${ }^{[14]}$ showed greater quadriceps irregularities with greater hamstring (antagonistic) activity during isokinetic testing in subjects with ACL deficiency and reconstructed ACLs. These findings suggest that injured knees remain impaired even after reconstruction. It is clear that ACL reconstruction may restore anterior static knee stability; however, there is no evidence that neuromuscular stability can be established by current surgical procedures. The restoration of normal neuromuscular control after ACL reconstruction is multifactorial in nature. ${ }^{[22]}$ Impairment in the neuromuscular modulation system may therefore also be responsible for the shifting angle of peak torque. Other morphologic impairments in hamstring torque-time curves were reported when comparing patients with ACL deficiency, patients who had undergone ACL reconstruction with the patellar tendon, and control subjects, although the hamstring peak flexion torque was not influenced by ACL reconstruction. ${ }^{[13]}$ This indicates that a single peak torque evaluation gives information about torque output, but may not always give sufficient information about the status of torque production quality following ACL reconstruction. ${ }^{[15]}$

A limitation of this study is that previous research has shown conflicting results regarding the reliability of the angle of peak torque. Reproducibility ranges from low to high among these previous studies. ${ }^{[23-25]}$ Reproducibility of the joint angle at the occurrence of maximum torque is directly dependent on several factors: joint congruency, the muscular group tested, angular velocity (endurance vs. explosive strength), and the type of contraction. Therefore, studies demonstrating low and high reliabilities should be evaluated under these specific test conditions. Clinicians should be aware that the angle of peak torque reproducibility may vary depending on the test protocol, contraction type, muscle fiber type, and angular velocity. Similarly, although the reliability of muscle torque measurement using the IsoMed 2000 has been reported, ${ }^{[26]}$ to our knowledge, no studies have investigated the angle of peak torque with this device. Therefore, a familiarization session prior to the actual test was performed in our study to minimize the effects of learning on torque production and maximize the reliability of the test measurements.

In this study, possible effects of shifts in the angle of peak torque on functional performance were not directly assessed. Therefore, additional research is needed to clarify the functional and clinical importance of these parameters in ACLreconstructed knees.

Another limitation of this study is that although the sample size was sufficient, the number of patients was uneven between the two groups. More patients underwent reconstruction with hamstring than patellar tendon grafts. We acknowledge that evenly numbered groups would have allowed for a more precise statistical analysis in some parameters; however, it did not affect the side-to-side comparison result which is the main finding of the study.

In conclusion, the angle of peak torque is affected after ACL reconstruction using either autogenous hamstring tendon or patellar tendon grafts. This could be important for clinicians in terms of preventing re-injury. Measuring of peak torque angle may be beneficial after ACL reconstruction. Exercises including eccentric contraction that can change the force production angle may be considered in return to sport phase of the rehabilitation program.

\section{Declaration of conflicting interests}

The authors declared no conflicts of interest with respect to the authorship and/or publication of this article.

\section{Funding}

The authors received no financial support for the research and/or authorship of this article.

\section{REFERENCES}

1. Atik OŞ. What is the role of the conservative intervention in the treatment of a torn anterior cruciate ligament? Eklem Hastalik Cerrahisi 2015;26:97-9.

2. Feller JA, Webster KE. A randomized comparison of patellar tendon and hamstring tendon anterior cruciate ligament reconstruction. Am J Sports Med 2003;31:564-73. 
3. Norte GE, Knaus KR, Kuenze C, Handsfield GG, Meyer $\mathrm{CH}$, Blemker SS, et al. MRI-Based Assessment of Lower Extremity Muscle Volumes in Patients Before and After ACL Reconstruction. J Sport Rehabil 2017:1-25.

4. Konishi Y, Oda T, Tsukazaki S, Kinugasa R, Fukubayashi T. Relationship between quadriceps femoris muscle volume and muscle torque at least 18 months after anterior cruciate ligament reconstruction. Scand J Med Sci Sports 2012;22:791-6.

5. Ageberg E, Roos HP, Silbernagel KG, Thomeé R, Roos EM. Knee extension and flexion muscle power after anterior cruciate ligament reconstruction with patellar tendon graft or hamstring tendons graft: a cross-sectional comparison 3 years post surgery. Knee Surg Sports Traumatol Arthrosc 2009;17:162-9.

6. Eitzen I, Grindem H, Nilstad A, Moksnes H, Risberg MA. Quantifying Quadriceps Muscle Strength in Patients With ACL Injury, Focal Cartilage Lesions, and Degenerative Meniscus Tears: Differences and Clinical Implications. Orthop J Sports Med 2016;4:2325967116667717.

7. Bell DR, Trigsted SM, Post EG, Walden CE. Hip Strength in Patients with Quadriceps Strength Deficits after ACL Reconstruction. Med Sci Sports Exerc 2016;48:1886-92.

8. Goetschius J, Hart JM. Knee-Extension Torque Variability and Subjective Knee Function in Patients with a History of Anterior Cruciate Ligament Reconstruction. J Athl Train 2016;51:22-7.

9. Atik OŞ, Erdoğan D, Seymen CM, Bozkurt HH, Kaplanoğlu GT. Is there crosstalk between subchondral bone, cartilage, and meniscus in the pathogenesis of osteoarthritis? Eklem Hastalik Cerrahisi 2016;27:62-7.

10. Xergia SA, McClelland JA, Kvist J, Vasiliadis HS, Georgoulis $\mathrm{AD}$. The influence of graft choice on isokinetic muscle strength 4-24 months after anterior cruciate ligament reconstruction. Knee Surg Sports Traumatol Arthrosc 2011;19:768-80.

11. Tsepis E, Giakas G, Vagenas G, Georgoulis A. Frequency content asymmetry of the isokinetic curve between ACL deficient and healthy knee. J Biomech 2004;37:857-64.

12. Ikeda H, Kurosawa H, Kim SG. Quadriceps torque curve pattern in patients with anterior cruciate ligament injury. Int Orthop 2002;26:374-6.

13. Bryant AL, Clark RA, Pua YH. Morphology of hamstring torque-time curves following ACL injury and reconstruction: mechanisms and implications. J Orthop Res 2011;29:907-14.
14. Bryant AL, Pua YH, Clark RA. Morphology of knee extension torque-time curves following anterior cruciate ligament injury and reconstruction. J Bone Joint Surg [Am] 2009;91:1424-31.

15. Brockett CL, Morgan DL, Proske U. Predicting hamstring strain injury in elite athletes. Med Sci Sports Exerc 2004;36:379-87.

16. Proske U, Morgan DL, Brockett CL, Percival P. Identifying athletes at risk of hamstring strains and how to protect them. Clin Exp Pharmacol Physiol 2004;31:546-50.

17. Henriksson M, Ledin T, Good L. Postural control after anterior cruciate ligament reconstruction and functional rehabilitation. Am J Sports Med 2001;29:359-66.

18. Makihara Y, Nishino A, Fukubayashi T, Kanamori A. Decrease of knee flexion torque in patients with ACL reconstruction: combined analysis of the architecture and function of the knee flexor muscles. Knee Surg Sports Traumatol Arthrosc 2006;14:310-7.

19. Melnyk M, Faist M, Gothner M, Claes L, Friemert B. Changes in stretch reflex excitability are related to "giving way" symptoms in patients with anterior cruciate ligament rupture. J Neurophysiol 2007;97:474-80.

20. Dyhre-Poulsen P, Krogsgaard MR. Muscular reflexes elicited by electrical stimulationof the anterior cruciate ligament in humans. J Appl Physiol 2000;89:2191-5.

21. Johansson H, Sjölander P, Sojka P. A sensory role for the cruciate ligaments. Clin Orthop Relat Res 1991;268:161-78.

22. Hewett TE, Di Stasi SL, Myer GD. Current concepts for injury prevention in athletes after anterior cruciate ligament reconstruction. Am J Sports Med 2013;41:216-24.

23. Maffiuletti NA, Bizzini M, Desbrosses $K$, Babault N, Munzinger U. Reliability of knee extension and flexion measurements using the Con-Trex isokinetic dynamometer. Clin Physiol Funct Imaging 2007;27:346-53.

24. Frontera WR, Hughes VA, Dallal GE, Evans WJ. Reliability of isokinetic muscle strength testing in 45- to 78-year-old men and women. Arch Phys Med Rehabil 1993;74:1181-5.

25. Bernard PL, Amato M, Degache F, Edouard P, Ramdani S, Blain $\mathrm{H}$, et al. Reproducibility of the time to peak torque and the joint angle at peak torque on knee of young sportsmen on the isokinetic dynamometer. Ann Phys Rehabil Med 2012;55:241-51.

26. Dirnberger J, Kosters A, Muller E. Concentric and eccentric isokinetic knee extension: A reproducibility study using the IsoMed 2000-dynamometer. Isokinetics and Exercise Science 2012;20:31-5. 